\title{
Cytogenetic characterization of Brycon amazonicus (Spix et Agassiz, 1829) (Teleostei: Characidae) from Caicara del Orinoco, Venezuela
}

\author{
T.C. Mariguela ${ }^{1}$, M. Nirchio ${ }^{2}$, E. Ron ${ }^{2}$, J.I. Gaviria ${ }^{2}$, F. Foresti ${ }^{1}$, C. Oliveira ${ }^{1}$ \\ ${ }^{1}$ Laboratório de Biologia e Genética de Peixes, Universidade Estadual Paulista \\ (UNESP), Departamento de Morfologia, Botucatu, SP, Zip code: 18618-970, Brazil. \\ ${ }^{2}$ Escuela de Ciencias Aplicadas del Mar, Núcleo de Nueva Esparta, Universidad de \\ Oriente. Apartado 174, Porlamar, Margarita,Venezuela. \\ E-mails: tatimariguela@gmail.com,nirchio@cantv.net, ronernesto@hotmail.com, \\ gaviria.ji@gmail.com, fforesti@ibb.unesp.br, claudio@ibb.unesp.br
}

\begin{abstract}
A cytogenetic analysis by conventional Giemsa staining, silver staining, C-banding, and fluorescence in situ hybridization (FISH) was carried out on Brycon amazonicus from Caicara del Orinoco, Venezuela. The karyotype of this species is characterized by the presence of $2 \mathrm{n}=50$ chromosomes, a karyotypic formula $22 \mathrm{~m}+14 \mathrm{sm}+14 \mathrm{st}$, and a fundamental number of 100 chromosomal arms. Nucleolar organizer regions (NORs) and 18S rDNA genes are located in the terminal regions of the long arms of the second pair of subtelocentric chromosomes, corresponding to pair 13. C-banding revealed heterochromatin distribution in only seven chromosome pairs. The largest metacentric pair (number 1) possesses a paracentromeric block equilocally distributed in both chromosome arms, whereas in pairs 12 to 17 positive $\mathrm{C}$ band blocks were located in the paracentromeric region of the long arm, close to the centromere. Analysis performed with 5S rDNA gene revealed a terminal site located on the short arm of one small submetacentric chromosome (pair 15) corroborating previous studies with this repetitive gene showing an apparent conservation of $5 \mathrm{~S}$ rDNA in the genome of these fish species. The data obtained in this study reinforce the chromosomal conservativeness in the species of the genus Brycon, related not only to the macro-chromosomal structure (diploid number, karyotypic formula, and fundamental number), but also to the repeated DNAs, such as heterochromatic regions and ribosomal DNAs. These data will contribute to a better understanding of chromosomal evolution in both Brycon and Characidae fishes.
\end{abstract}

Key words: Characidae, C-banding, karyotype, NORs, 18S rDNA, 5S rDNA.

\section{INTRODUCTION}

Characidae is the largest family of Characiformes and comprises about $55 \%$ of freshwater fishes of this group (Fink, Fink, 1981). Due to their great adaptive capacity, a large variety of species presenting distinct shape and life habits, which probably form a polyphyletic group (Nelson, 2006), are found within this family. Distributed from Southern Mexico to Argentina, Bryconinae is a Characidae subfamily composed of 43 species subdivided in three genera, among which Brycon Müller et Troschel, 1844 is the most diverse with 41 species until now. The two other 
genera of this subfamily, Chilobrycon Géry, de Rham, 1981 and Henochilus Garman, 1890, are monotypic (Lima et al., 2003). Some species of Bryconinae are of great economic interest due to their fast growth and low mortality rates, good breeding performance, and better resistance to parasitic diseases (Baras et al., 2000; Beltrán-Turriago, 2001; Moreira et al., 2001; Figueiredo-Garutti et al., 2002; Silva et al., 2002). However, human activities have threatened or led to the extinction of some populations (Braga, 1982), and conservation programs are badly needed.

Even though fishes of this genus are of great economic importance, studies concerning biological and genetic aspects are scarce. Cytogenetics may become an important source of information for taxonomy and for understanding the relationships between species; besides, this information is also useful for the analysis of genome structure and chromosomal evolution. In Brycon chromosomes have been investigated in nine species (see Table 1), which represent less than $25 \%$ of the species in the genus, under the focus of classical and molecular cytogenetic.

In Venezuela, besides B. amazonicus (Spix et Agassiz, 1829), seven species of Brycon have been reported, four of which are endemic (B. bicolor Pellegrin, 1909 and B. coquenani Steindachner, 1915 from the Orinoco river basin and $B$. polylepis Mosco Morales, 1988 and B. unicolor Mosco Morales, 1988 from the lake Maracaibo basin) (Lima et al., 2003; Froese, Pauly, 2008); but so far these species have not yet been investigated from a cytogenetic point of view.

The karyotype, including diploid number, chromosomal formulae, and fundamental number of Brycon amazonicus from Colombia, referred as to $B$. siebenthalae, was studied by Parada et al. (2003). Here we enhanced the chromosomal information for this species performing classical, chromosomal banding (C-banding and silver nitrate staining), and fluorescence in situ hybridization (FISH) for ribosomal genes (18S and 5S rRNA) in one population from Venezuela. These results will contribute to a better knowledge of karyotypic differentiation in Brycon related to the macrochromosomal structure and repeated DNAs.

\section{Material AND METHOdS}

Ten specimens (five females and five males) of Brycon amazonicus from Laguna de Castilleros, Caicara del Orinoco, Estado Bolívar, Venezuela, were analyzed. Voucher specimens were kept in the fish collection of Escuela de Ciencias Aplicadas del Mar, Universidad de Oriente, Venezuela, and Laboratório de Biologia e Genética de Peixes, Instituto de Biociências, UNESP, Brasil (LBP 1975).

Chromosome preparations were carried out following the technique described by Foresti et al. (1993). For the determination of diploid number, karyotype formula, and fundamental number $(\mathrm{FN})$, the preparations were stained with $10 \%$ Giemsa for 10 minutes in a phosphate buffer at $\mathrm{pH}$ 6.88. The nucleolar organizer regions (NORs) were detected by the silver nitrate $\left(\mathrm{AgNO}_{3}\right)$ staining method (Howell, Black, 1980) and the distribution of the constitutive heterochromatin (C-band) was obtained according to Sumner (1972).

For in situ hybridization, fragments of the two genes were obtained from the genomic DNA extracted from muscle (Aljanabi, Martinez, 1997) of B. amazonicus through Polymerase Chain Reaction (PCR). The primers: 5SA (5'TAC GCC CGA TCT CGT CCG ATC3') and 5SB (5'CAG GCT GGT ATG GCC GTA AGC3'), described by Pendás et al. (1994), were used for 5S rRNA gene and NS1 (5'GTA GTC ATA TGC TTG 
TCTC3') and NS8 (5'TCC GCA GGT TCA CCT ACG GGA3'), described by White et al. (1990), for $18 \mathrm{~S}$ rRNA gene. The $18 \mathrm{~S}$ rDNA and $5 \mathrm{~S}$ rDNA probes were labeled by nick translation with biotin-14-dATP (BionickTM Labelling System-Gibco BRL) following the manufacturer's instructions.

FISH was carried out according to Pinkel et al. (1986). The slides with metaphase chromosomes were incubated with RNAse $(40 \mu \mathrm{g} / \mathrm{ml})$ at $37^{\circ} \mathrm{C}$ for $1 \mathrm{~h}$. After DNA denaturation in $70 \% / 2 \times \mathrm{xSC}$ formamide at $70^{\circ} \mathrm{C}$ for 2 minutes, the chromosome preparations were dehydrated in an ethanol series $(70,85$, and $100 \%)$. After drying, the hybridization mix (100 $\mathrm{ng}$ probes, $10 \mathrm{mg} / \mathrm{ml}$ dextran sulfate, $2 \times \mathrm{xSC}$, and $50 \%$ formamide in a $30 \mu$ f final volume) was denatured at $95^{\circ} \mathrm{C}$ for $10 \mathrm{~min}$ and put onto the slides, which were then incubated overnight at $37^{\circ} \mathrm{C}$ in a humid chamber. After hybridization, the slides were washed in 2XSSC with shaking for 5 minutes at $72^{\circ} \mathrm{C}$; the slides were then incubated in PBD solution for 5 minutes at room temperature. Probe detection was done with $0.07 \%$ avidinFITC (Sigma) conjugated with NFDM/4xSSC buffer for 30 minutes, followed by signal amplification using $2.5 \%$ antividin-biotin conjugated with NFDM/4xSSC buffer for 30 minutes. Treatments with avidin-FITC and antividin-biotin were accomplished at $37^{\circ} \mathrm{C}$ in a humid chamber. After each step for signal detection, preparations were washed 3 times with PBD for 5 minutes at $45^{\circ} \mathrm{C}$. Chromosomes were counterstained with DAPI $(0.2 \%)$ in vectashield medium.

Mitotic chromosomes were photographed using a digital camera and images were digitally processed with Adobe Photoshop v. 7.0. The karyogram was constructed with chromosomes organized in size decreasing order. Chromosomes were classified following Levan et al. (1964). FISH metaphases were photographed with an Olympus BX61 photomicroscope equipped with a DP70 digital camera.

\section{RESULTS}

Specimens of both sexes of $B$. amazonicus showed a diploid number $2 \mathrm{n}=50$ (all bi-armed), with the karyotype formula $22 \mathrm{~m}+14 \mathrm{sm}+14 \mathrm{st}$ and $\mathrm{FN}=100$ (Fig. 1, a). The first pair of the metacentric series was classified as homologous due to its very large size in regard to the other elements of the series. Slight differences in chromosome size of pairs 2 to 11 made the identification of chromosomal homologies difficult. In the submetacentric series, only pairs 12 and 13 could be accurately classified as homologous.

In this study, C-banding revealed heterochromatin distribution in only seven chromosome pairs (Fig. 1, b). The largest metacentric pair (number 1) possesses a paracentromeric block equilocally distributed on both chromosome arms, whereas in pairs 12 to 17 of the submetacentric series positive C-band blocks were located in the paracentromeric region of the long arm, close to the centromere (Fig. 1, b).

The silvernitrate $\left(\mathrm{AgNO}_{3}\right)$ staining revealed signals in the terminal region of long arms of the second pair of subtelocentric chromosomes (Fig. 1a inset). Metaphases analyzed by FISH with $18 \mathrm{~S}$ rDNA probes confirmed the results obtained by silver nitrate staining, revealing fluorescent signals of $18 \mathrm{~S}$ rDNA also located in the terminal region of the long arms of pair 13 (Fig. 2, a). Furthermore, the FISH revealed also very week additional signals in the interstitial position in two chromosome pairs (one in a large submetacentric, and another in a large subtelocentric). The mapping of $5 \mathrm{~S}$ rDNA through FISH revealed non syntenic clusters in comparison with the 18S rDNA, 


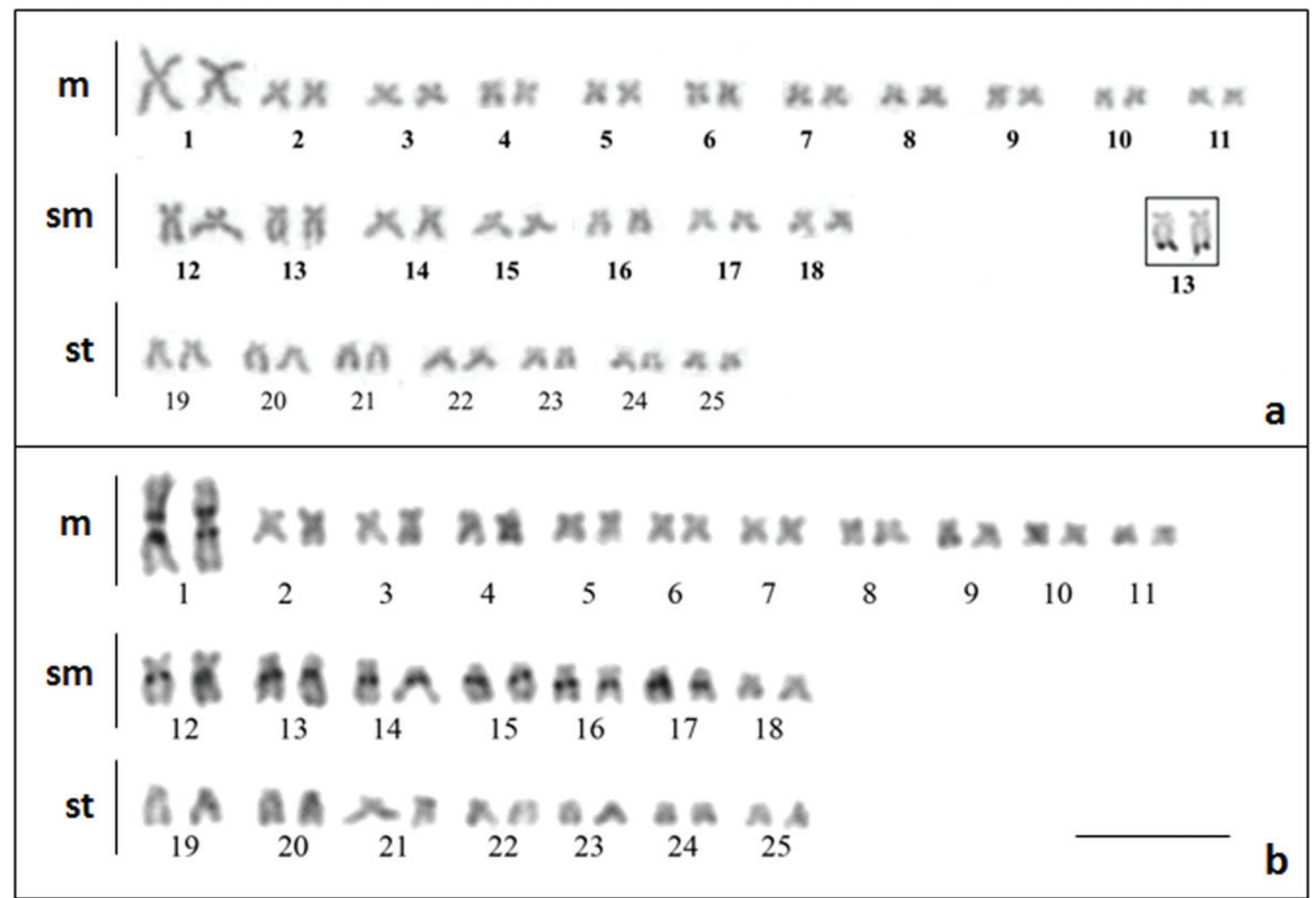

Fig. 1, a-b. a - Standard karyotype of Brycon amazonicus and sequential staining (inset) of NORs showing the chromosome on which they are located. b - C-Band karyotype of Brycon amazonicus showing the chromosomes on which the bands are located. $\mathrm{m}=$ metacentric, $\mathrm{sm}=$ submetacentric, $\mathrm{st}=$ subtelocentric. $\mathrm{Bar}=10 \mu \mathrm{m}$.

being the 5S rDNA sites located on the short arm of one small submetacentric chromosome (pair 15) (Fig. 2, b). Moreover, similar to 18S rDNA, additional small fluorescent signals were observed in the interstitial region of two large submetacentric pairs using the 5S rDNA probes.

\section{Discussion}

The presence of a large metacentric chromosome pair seems to be a common feature for species in the genus Brycon and has been perceived as a chromosome marker in the Bryconinae (Parada et al., 2003; López et al., 2008). The diploid number observed in $B$. amazonicus $2 \mathrm{n}=50$ has also been described by different authors in other species of the genus (Table 1), which may indicate a chromosomal stability in this group. Oliveira et al. (1988) indicated a tendency of a karyotype composed of $2 n=50$ with primarily meta and submetacentric chromosomes in Ostariophysi fishes to comprise three more orders besides Characiformes: Cypriniformes, Siluriformes, and Gymnotiformes.

Parada et al. (2003) described the karyotype of $B$. amazonicus from Colombia with $2 n=50$ and 24 metacentric elements and a remarkable presence of one large metacentric pair (number 1) and 26 chromosomes classified as $\mathrm{sm} / \mathrm{st}(24 \mathrm{~m}+26 \mathrm{sm} / \mathrm{st})$. On the other hand, our analysis indicated distinct karyotypic 

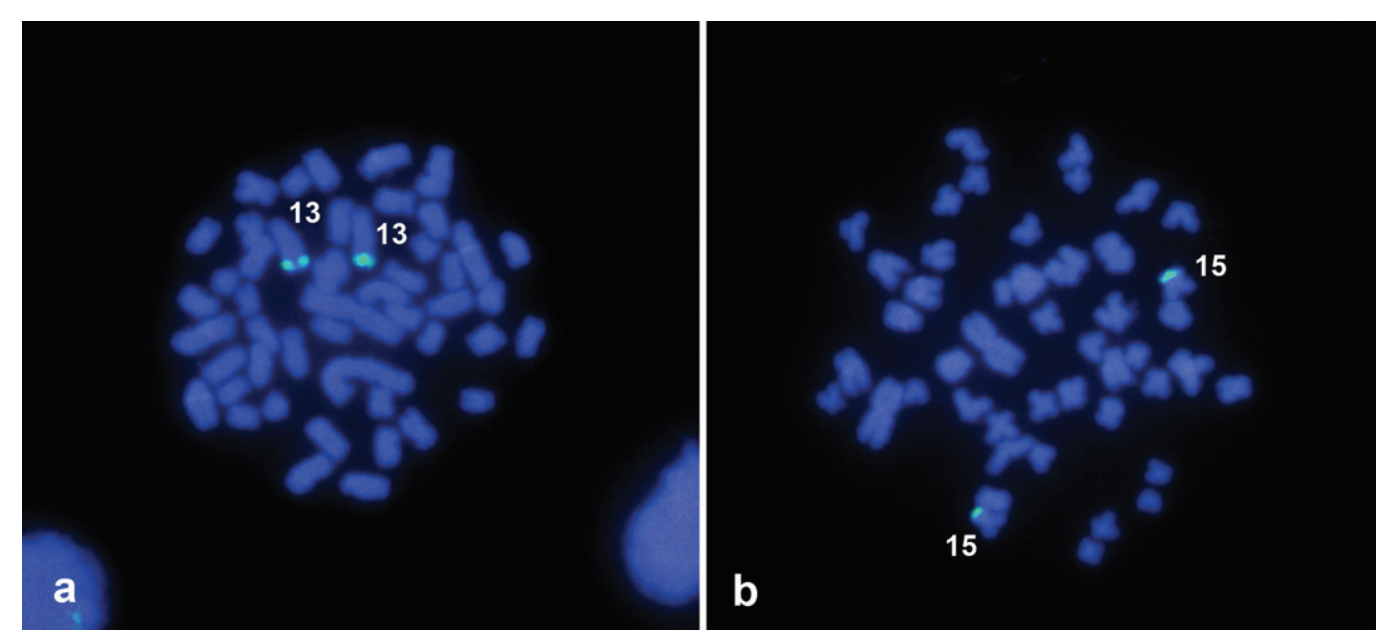

Fig. 2. Mitotic metaphases showing the chromosomal location of (a) $18 \mathrm{~S}$ rDNA and (b) 5S rDNA clusters by fluorescence in situ hybridization. Scale bar is not shown.

formulae for this species, with the presence of $22 \mathrm{~m}+14 \mathrm{sm}+14$ st. These distinct chromosomal formulae could indicate the presence of well-defined cytotypes for $B$. amazonicus as the result of differentiation process in the two populations studied. Another possible explanation for the differences between the chromosome formulae previously published and the results presented here should take into account the apparent impossibility of distinguishing the $\mathrm{sm} / \mathrm{st}$ elements due to the excessive condensation of the chromosomes, as observed in the karyogram provided by Parada et al. (2003). The chromosomal data available for the genus Brycon (Table 1) indicate the presence of a common ancestral karyotype, with a basic diploid number $2 \mathrm{n}$ $=50$, which have not suffered extensive chromosomal rearrangements, conserving the karyotypic structure in the genus. This hypothesis was also proposed by some other authors to explain the chromosomal stasis in Brycon (Margarido, Galetti, 1999; Parada et al., 2003; Brassesco et al., 2004).

Concerning the heterochromatin distri- bution the presence of a large metacentric pair bearing equilocal paracentromeric heterochromatin on both chromosome arms observed in the karyotype of $B$. amazonicus was also described in B. orthotaenia Günther, 1864 and B. hilarii (Valenciennes, 1850), although, distinct patterns concerning the other chromosomes were observed among these three species. Besides the heterochromatin observed in the submetacentric elements, some other metacentric chromosomes showed $C$ positive bands in pairs 2 and 3 in $B$. hilarii and in pairs 2 and 6 in B. orthotaenia. Moreover, the heterochromatin distribution of submetacentric chromosomes was also distinct (Margarido, Galetti, 1999). So far, several distribution patterns of constitutive heterochromatin have been observed in different species of Brycon analyzed thus far. According to Margarido, Galetti (1996), the changes in constitutive heterochromatin distribution pattern can play an important role in the chromosomal differentiation of this fish group, and are distributed in at least two general patterns. One group presents $\mathrm{C}$-bands 
Table 1. Diploid number (2n), fundamental number (FN), karyotypic formulae, number of the nucleolar organizer regions (NORs), and banding types performed in different Brycon species. Chromosome types: $\mathrm{m}=$ metacentric; $\mathrm{sm}=$ submetacentric; $\mathrm{st}=$ subtelocentric. Banding types: $\mathrm{C}=\mathrm{C}$-Banding, $\mathrm{F}=\mathrm{FISH}, \mathrm{M}=$ Mitromicin.

\begin{tabular}{|c|c|c|c|c|c|c|c|}
\hline $\begin{array}{c}\text { Current } \\
\text { Species Name }\end{array}$ & $\begin{array}{c}\text { Referred } \\
\text { Species Name }\end{array}$ & $2 n$ & $\begin{array}{l}\text { Karyotype } \\
\text { Formulae }\end{array}$ & FN & NOR & Banding & References \\
\hline B. cephalus & & 50 & $24 \mathrm{~m}+26 \mathrm{sm} / \mathrm{st}$ & ----- & 1 & $\mathrm{C}$ & Almeida-Toledo et al., 1996 \\
\hline B. cephalus & & 50 & $24 m+20 s m+6 s t$ & 94 & ------- & $\mathrm{C}, \mathrm{M}$ & Margarido, Galetti, 1996 \\
\hline B. cephalus & & 50 & $\begin{array}{ll}------ \\
\end{array}$ & \begin{tabular}{|l|}
------- \\
\end{tabular} & 1 & $\mathrm{~F}$ & Wasko, Galetti, 2000 \\
\hline B. falcatus & B. brevicauda & 50 & $20 \mathrm{~m}+24 \mathrm{sm}+6 \mathrm{st}$ & 94 & 1 & $\mathrm{C}, \mathrm{M}$ & Margarido, Galetti, 1996 \\
\hline B. henni & & 50 & $26 \mathrm{~m}+16 \mathrm{sm}+8 \mathrm{st}$ & 100 & $\begin{array}{ll}------ \\
\end{array}$ & $\begin{array}{ll}------- \\
\end{array}$ & López et al., 2008 \\
\hline B. hilarii & B. microlepis & 50 & $20 m+24 s m+6 s t$ & 94 & 1 & $\mathrm{C}, \mathrm{M}$ & Margarido, Galetti, 1996 \\
\hline B. insignis & & 50 & $26 \mathrm{~m}+24 \mathrm{sm} / \mathrm{st}$ & ------- & 1 & $\mathrm{C}$ & Almeida-Toledo et al., 1996 \\
\hline B. insignis & & 50 & $24 m+20 s m+6 s t$ & 94 & 1 & $\mathrm{C}, \mathrm{M}$ & Margarido, Galetti, 1996 \\
\hline B. nattereri & B. reinhar & 50 & $22 \mathrm{~m}+28 \mathrm{sm} / \mathrm{st}$ & $\begin{array}{l}---- \\
---1\end{array}$ & 1 & $\mathrm{C}$ & Almeida-Toledo et al., 1996 \\
\hline B. orthotaenia & B. lundii & 50 & $22 m+24 s m+4 s t$ & 96 & ------ & $\mathrm{C}, \mathrm{M}$ & Margarido, Galetti, 1996 \\
\hline B. orthotaenia & B. lundii & 50 & ------- & \begin{tabular}{|l|l|}
$------~$ \\
\end{tabular} & ------- & $\mathrm{F}$ & Wasko, Galetti, 2000 \\
\hline B. orbignyanus & & 50 & $24 m+22 s m+4 s t$ & 96 & ------- & $\mathrm{C}, \mathrm{M}$ & Margarido, Galetti, 1996 \\
\hline B. amazonicus & B. siebenthalae & 50 & $24 \mathrm{~m}+26 \mathrm{sm} / \mathrm{st}$ & ------- & ------- & ------- & Parada et al., 2003 \\
\hline B. amazonicus & & 50 & $22 \mathrm{~m}+14 \mathrm{sm}+14 \mathrm{st}$ & 100 & 1 & $\mathrm{C}, \mathrm{F}$ & This study \\
\hline
\end{tabular}

located primarily in some submetacentric chromosomes, as observed in B. amazonicus, and another one with species characterized by the presence of heterochromatin in the telomeric region of some metacentric elements. These differences may be important cytogenetic markers that could be used for differentiation of populations and/or species of Brycon.

A remarkable stability of the Nucleolar Organizer Region(NOR) pattern, characterized by the presence of NORs in a single chromosome pair, has been recognized as a common characteristic of all Brycon species studied and proposed as a primitive feature in the subfamily Bryconinae (Wasko, Galetti, 2000). In B. amazonicus, metaphases exposed to silver impregnation also showed only one NOR- bearing chromosome pair, located in the terminal region of the long arms of the second pair of subtelocentric chromosomes, which correspond in number and locations to those found in other species of this genus analyzed to date (Table 1). The presence of only one NOR-bearing chromosome is also the most widespread characteristic among teleosts (Vitturi et al., 1995).

The FISH for 18S rDNA probes confirmed the results obtained by silver nitrate staining. Similar results were found comparing the studies with silver nitrate staining (Margarido, Galetti, 1996) and FISH with an 18S rDNA probe (Wasko, Galetti, 2000), with the occurrence of two NORs (rDNA sites) in the end of the long arm of a unique large submetacentric pair in all seven species of Brycon analyzed. Furthermore, the FISH observations revealed very week additional signals in the interstitial position in two chromosome pairs, contrasting with the results described by Wasko, Galetti (2000) for other Brycon species. The FISH technique using 18S rDNA sequences has identified a higher number of major ribosomal cistrons than the Ag-NOR technique in several species of fish: Salmo trutta Linnaeus, 1758 (Pendás et al., 
1993), Astyanax scabripinnis (Jenyns, 1842) (Ferro et al., 2001), Hyphessobrycon anisitsi (Eigenmann, 1907) (Centofante et al., 2003), Prochilodus lineatus (Valenciennes, 1836) (Jesus, Moreira-Filho, 2003), Colossoma macropomum (Cuvier, 1818), Piaractus brachypomus (Cuvier, 1818) and their interspecific hybrids (Nirchio et al., 2003), Lebias fasciata Valenciennes, 1821 (Tigano et al., 2004) and Triportheus venezuelensis Spix, 1829 (Nirchio et al., 2007). Even though these signals may be technical artifacts, they would also represent chromosome regions with NORs that are usually unexpressed, due to DNA methylation and gene silencing related to positional effects induced by heterochromatin (C-bands) and/or telomeres, as suggested by Guillén et al. (2004).

In this study, the 5S rDNA sites were not syntenic to the NORs found in B. amazonicus, corroborating the results previously published by Wasko et al. (2001) on other Brycon species. A study performed by Wasko et al. (2001) aiming to characterize the nucleotide sequence and chromosomal localization of the 5S rDNA in seven species of the genus Brycon (B. orthotaenia, B. hilarii, B. orbignyanus (Valenciennes, 1850), B. cephalus (Günther, 1869), Brycon sp., B. falcatus Müller, Trochel, 1844, and B. insignis Steindachner, 1877) revealed that the 5S rRNA genes were highly conserved, while only the non-transcribed spacers (NTSs) were widely variable among the species analyzed. In relation to the number of sites, the same study revealed the presence of only one bivalent bearing this gene sequence in other six Brycon species, indicating an apparent conservation of 5S rDNA in the genome of these fish species. Similar to $18 \mathrm{~S}$ rDNA, additional small fluorescent signals could be observed using the 5S rDNA probes (two large submetacentric pairs), all in interstitial position. Although these signals may represent only technical artifacts, they can also represent chromosome regions with a very low number of copies of those genes. This was also observed by Wasko et al. (2001) in B. orthotaenia, B. orbignyanus, B. hilarii, B. cephalus, Brycon sp. and B. falcatus.

The data obtained in this study reinforce the chromosomal stability in the species of the genus Brycon, related not only to the macro-chromosomal structure (diploid number, karyotypic formulae and fundamental number), but also to the repeated DNAs, such as heterochromatic regions and ribosomal DNAs. These data will contribute to a better understanding of chromosomal evolution in Brycon and in Characidae fishes.

\section{ACKNOWLEDGEMENTS}

This work was supported by Consejo de Investigación, Universidad de Oriente, Venezuela, Conselho Nacional de Desenvolvimento Científico e Tecnológico (CNPq), and Fundação de Amparo à Pesquisa do Estado de São Paulo (FAPESP), Brazil.

\section{REFERENCES}

Aljanabi S.M., Martinez I. 1997. Universal and rapid salt-extraction of high quality genomic DNA for PCR-based techniques // Nucleic Acids Res. 25(22): 4602-4603.

Almeida-Toledo L.F., Bigoni A.P., Bernardino G., Foresti F., Toledo-Filho S.A. 1996. Karyotype and NOR conservatism with heterochromatin reorganization in Neotropical Bryconids // Caryologia. 49: 35-43.

Baras E., Ndao M., Maxi M., Jeandrain D., Thome J.P., Vanderwalle P., Mélard C. 2000. Sibling cannibalism in dorada under experimental conditions. I. Ontogeny, dynamics, bioenergetics of cannibalism and prey size selectivity // J. Fish Biol. 57: 1001-1020.

Beltrán-Turriago C.S. 2001. Promoción de la ordenación de la pesca costera: 2. Aspectos socioeconómicos y técnicos de la pesca artesanal en El Salvador, Costa Rica, Panamá, Ecuador y 
Colombia // FAO Circular de Pesca. No. 957/2. Roma, FAO. 2001. 71 p.

Braga R.A. 1982. Depleção aparente do matrinxã, Brycon hilarii, em pesqueiros do Rio São Francisco // Bol. Técn. Depart. Obras Contras Secas (Brazilea). 40: 175-180.

Brassesco M.S., Pastoril M.C., Roncati H.A., Fenocchio A.S. 2004. Comparative cytogenetic studies of Curimatidae (Pisces, Characiformes) from the middle Parana River (Argentina) // Gen. Mol. Res. 3: 293-301.

Centofante L., Bertollo L.A.C., Miyazawa C.S., Moreira-Filho O. 2003. Chromosomal differentiation among allopatric populations of Hyphessobrycon anisitsi (Pisces, Tetragonopterinae) // Cytologia. 68(3): 283-288.

Ferro D.A.M., Néo D.M., Moreira-Filho O., Bertollo L.A.C. 2001. Nucleolar organizing regions, $18 \mathrm{~S}$ and 5S rDNA in Astyanax scabripinnis (Pisces, Characidae): populations distribution and functional diversity // Genetica. 110: 55-62.

Figueiredo-Garutti M.L., Navarro I., Capilla E., Souza R.H.S., Moraes G., Gutierrez J., VicentiniPaulino M.L.M. 2002. Metabolic changes in Brycon cephalus (Teleostei,Characidae ) during post-feeding and fasting // Comp. Biochem Physiol. 132(A): 467-476.

Fink S.V., Fink W.L. 1981. Interrelationships of the osthariophysian fishes (Teleostei) // Zool. J. Linnean Soc. London. 72: 297-353.

Foresti F., Oliveira C., Galetti P.M., Almeida-Toledo L.F. 1993. Synaptonemal complex analysis in spermatocytes of tilapia, Oreochromis niloticus (Pisces, Cichlidae) // Genome. 36: 1124-1128.

Froese R., Pauly D. (Editors). 2010. FishBase. World Wide Web electronic publication. (www.fishbase. org, on May 20, 2010).

Guillén A.K.Z., Hirai Y., Tanoue T., Hirai H. 2004. Transcriptional repression mechanisms of nucleolus organizer regions (NORs) in humans and chimpanzees // Chromos. Res. 12:225-237.

Howell W.M., Black D.A. 1980. Controlled silverstaining of nucleolus organizer regions with a protective colloidal developer: a 1-step method // Experientia. 36: 1014-1015.

Jesus C.M., Moreira-Filho O. 2003. Chromosomal location of 5S and 18S rRNA genes in Prochilodus lineatus (Characiformes, Prochilodontidae) // Caryologia. 56(3): 281- 287.

Levan A., Fredga D., Sandberg A. 1964. Nomenclature for centromeric position on chromosomes // Hereditas. 52: 201-220.

Lima F.C.T., Malabarba L.R., Buckup P.A., Silva J.F.P., Vari R.P., Harold A., Benine R., Oyakawa O.T., Pavanelli C.S., Menezes N.A., Lucena C.A.S., Malabarba M.C.S.L., Lucena Z.M.S., Reis R.E., Langeani F., Cassati L., Bertaco V.A., Moreira C., Lucinda P.H.F. 2003. Genera Incertae Sedis in Characidae, (pp. 134-141) // Reis R.E. Kullander S.O. Ferraris Jr. C.J. (Eds). Check list of the freshwater fishes of South America. Porto Alegre, Brazil. 742p.

López D.D., Palacio G.V., Cortés T.R., Angel M.O. 2008. Caracterización citogenética del pez neotropical Brycon henni (Pisces: Characidae) // Rev. Biol. Trop. (Int. J. Trop. Biol.). 56(4): 16191628.

Margarido V.P., Galetti P.M. 1996. Chromosomes studies in fish of the genus Brycon (Characiformes, Characidae, Briconinae) // Cytobios. 85: 219-228.

Margarido V.P., Galetti P.M. 1999. Heterochromatin patterns karyotype relationships within and between the genera Brycon and Salminus (Pisces, Characidae) // Genet. Mol. Biol. 22(3): 357-361.

Moreira A.B., Visentainer J., de Souza J.E., Matsushita M. 2001. Fatty Acids Profile and Cholesterol Contents of Three Brazilian Brycon Freshwater Fishes // J. Food Compos. Anal. 14: 565-574.

Nelson J.S. 2006. Fishes of the world. 600 p.

Nirchio M., Cervigón F., Porto J.I.R., Pérez J.E., Gómez J.A., Villalaz J. 2003. Karyotype supporting Mugil curema Valenciennes, 1836 and Mugil gaimardianus Desmarest, 1831 (Mugilidae: Teleostei) as two valid nominal species // Sci. Mar. 67(1): 113-115.

NirchioM.,Oliveira C.,FerreiraI.A.,GranadoA.,Ron E. 2007. Extensive polymorphism and chromosomal characteristics of ribosomal DNA in the characid fish Triportheus venezuelensis (Characiformes, Characidae) // Genet. Mol. Biol. 30: 25-30.

Oliveira C., Almeida-Toledo L.F., Foresti F., Britski H.A., Toledo-Filho A.S. 1988. Chromosome formulae of Neotropical freshwater fishes // Rev. Bras. Genet. 11: 577-624.

Parada S., Arias J.A., Cruz P.E. 2003. Caracterizacón cariotípica del yamú (Brycon siebenthalae) // Revista Orinoquia. 7: 42-46.

Pendás A.M., Moran P., Freije J.P., Garcia-Vázquez E. 1994. Chromosomal location and nucleotide 
sequence of two tandem repeats of Atlantic salmon 5S rDNA// Cytogenet. Cell Gen. 67: 31-36.

Pendás A.M., Morán P., Garcia-Vázquez E. 1993. Ribosomal RNA genes are interspersed throughout a heterochromatic chromosome arm in Atlantic salmon // Cytogenet. Cell Genet. 63: 128-130.

Pinkel D., Straume T., Gray J.W. 1986. Cytogenetic analysis using quantitative, high-sensitivity, fluorescence hybridization // Proc. Nat. Acad. Sci. USA. 83: 2934-2938.

Silva A.W., Azeredo-Espin A.M., Krieger M.H., Krieger J.E. 2002. Mitochondrial DNA diversity in wild and cultured populations of Brycon opalinus (Cuvier, 1819) (Characiformes, Characidae, Bryconinae) from the Paraíba do Sul Basin, Brazil // Aquaculture. 214: 81-91.

Sumner A.T. 1972. A simple technique for demonstrating centromeric heterocromatin // Exp. Cell Res. 75: 304-306.

Sumner A.T. 1990. Chromosome banding. London. $434 \mathrm{p}$.

Tigano C., Rocco L., Ferrito V., Costagliola D., Pappalardo A.M., Stinso V. 2004. Chromosomal mapping and molecular characterization of ribosomal RNA genes in Lebias fasciata (Teleostei, Cyprinodontidae) // Genetica. 121: 95-100.
Vitturi R., Catalano E., Colomba M.S., Montagnino L., Pellerito L. 1995. Karyotype analysis of Aphanius fasciatus (Pisces, Cyprinodontiformes) Ag-NORs and C-band polymorphism in tour populations from Sicily // Biol. Zentralblatt. 114: 392-402.

Wasko A.P., Galetti P.M. 2000. Mapping 18s ribosomal genes in fish of the genus Brycon (Characidae) by fluorescence in situ hibridization (FISH) // Genet. Mol. Biol.. 23 (1): 135-138.

Wasko A.P., Martins C., Wright J.M., Galetti P.M. 2001. Molecular organization of $5 \mathrm{~S}$ rDNA in fishes of the genus Brycon // Genome. 44: 893-902.

White T.J., Bruns T., Lee S., Taylor J. 1990. Amplification and direct sequencing of fungal ribosomal RNA genes for phylogenetics in PCR protocols: a guide to methods and applications, (pp. 315-322) // Innis M.A. et al. (Eds). PCR protocols: a guide to methods and applications. San Diego. 482 p.

Received October 1, 2010.

Accepted by I.A. Gavrilov, December 14, 2010.

Published December 30, 2010. 